\title{
Cycling Behaviour Changes as a Result of COVID-19: A Survey of Users in Sydney, Australia.
}

Oliver Lock' $\odot$

${ }^{1}$ Faculty of Built Environment, University of New South Wales

Keywords: cycling, transportation, travel behaviour, covid-19, qualitative research, sydney, australia

https://doi.org/10.32866/001c.13405

Transport Findings

This research highlights transport findings related to individual and observed behaviours and self-reported attitudes towards cycling in Sydney, Australia during COVID-19 social distancing and lockdown restrictions in May, 2020. An online survey with $\mathrm{n}=250$ participants collected data pertaining to the question "How has cycling behaviour potentially changed as a result of COVID-19?". Thematic analysis is used to summarise the changes documented by these individuals - such as increased number of cyclists, increased volume of families and children on roads, reduced traffic, increased imperative for new cycle infrastructure and potential new permanent changes in their commuting behaviour away from public transport.

\section{RESEARCH QUESTION[s] AND HYPOTHESIS[ES]}

It has been articulated within the transport professional and research community that there will be widespread changes in the design and use of transport networks as a result of the COVID-19 pandemic - both in direct response to the virus, its prevention in future, higher uptake in remote work and observation of new healthier, more sustainable travel habits.

In the city of Sydney in Australia, social distancing measures heavily reduced the amount of private vehicles on the road, and combined with the temporary closure of indoor exercise facilities, and a need to simply 'get outside' by office workers working from home saw potentially new forms of uptake and behaviour regarding urban cycling. Generally, research on cycling in Sydney has identified an enthusiastic population of potential cyclists - in some cases showing latent demand (Rissel et al. 2010), while also coupling this with evidence of barriers to cycling such as limited success in measures such as bikesharing (Heymes 2019) and a need for more separated cycleways (Standen et al. 2017).

It is timely to document the experience of urban cyclists and how they personally perceived their travel habits changed during this time, as well as their experience of others. This research documents the zeitgeist of cyclists in the city Sydney, Australia during a time of government-mandated social distancing restrictions. It asks the research question: "How has cycling bebaviour potentially changed as a result of COVID-19? 


\section{METHODS AND DATA}

As part of a wider study on participatory tools for cycle planning, an online survey was sent out an open for two weeks in May 2020. The survey was circulated using the snowball sampling method - starting with the researchers' own contacts and then shared through various personal, professional and social media channels. The target audience for this was anyone in Sydney, over 18 years of age, who would be interested in undertaking the survey.

This research focuses on the analysis of one question of this survey which received an unprecedented level of detailed responses: 'Do you feel that the COVID-19 situation has changed your views or behaviours around cycling in any way? What about those around you? How?' The research closely examines the answers to this question - identifying and summarising common themes, topics and ideas.

\section{FINDINGS}

The sample for this study achieved 250 responses within a two-week period. Participants were from a diverse geographic range, residing in over 90 different postcodes throughout Sydney, shown in Figure 1. 64.4\% of participants identified as male, $34.4 \%$ as female and the remainder $1.2 \%$ as other gender identities. In terms of age brackets, $5.5 \%$ were $18-24,25 \%$ were $25-34$ or $45-54$, $30 \%$ were $35-44$ and the remainder were 55 and over. This is in line with other survey results involving cyclists, showing a skew towards middle-aged males for over 18-year-olds (Austroads 2019). Of the 250 responses, there were a total of 4,000 words averaging at approximately 16 words per response. In many examples, participants described in detail what was occurring in their lives.

This research follows a simple method of thematic analysis highlighted by Braun and Clarke (2006). Key codes were derived from reading all individual responses and counting the number of responses which matched these codes in a systematic way. A diagram summarising these codes can be found in Figure 2. In this figure, one can observe the codes from positive themes describing positive changes to participants' lives and perceptions of cycling (top-right), as well as negative changes (bottom left). From the analysis of these codes, more general themes were derived. Each of these themes, paired with key quotes, can be found summarised in Appendix 1, Table A1.

The key themes identified were that more (and, in many cases, described as 'new') cyclists were observed than usual, there was a reduced amount of traffic which influenced this, there was a collective stronger imperative for better cycling infrastructure, there were higher volumes of children and families cycling, new concerns for safety arose (mainly from more inexperienced cyclists sharing infrastructure), there was a general increased willingness to cycle (including new bike purchases) and there were potential changes in commuting behaviour as a result of hygiene reasons and newfound enjoyment in cycling. Through the analysis of these codes, themes and key quotes, this 


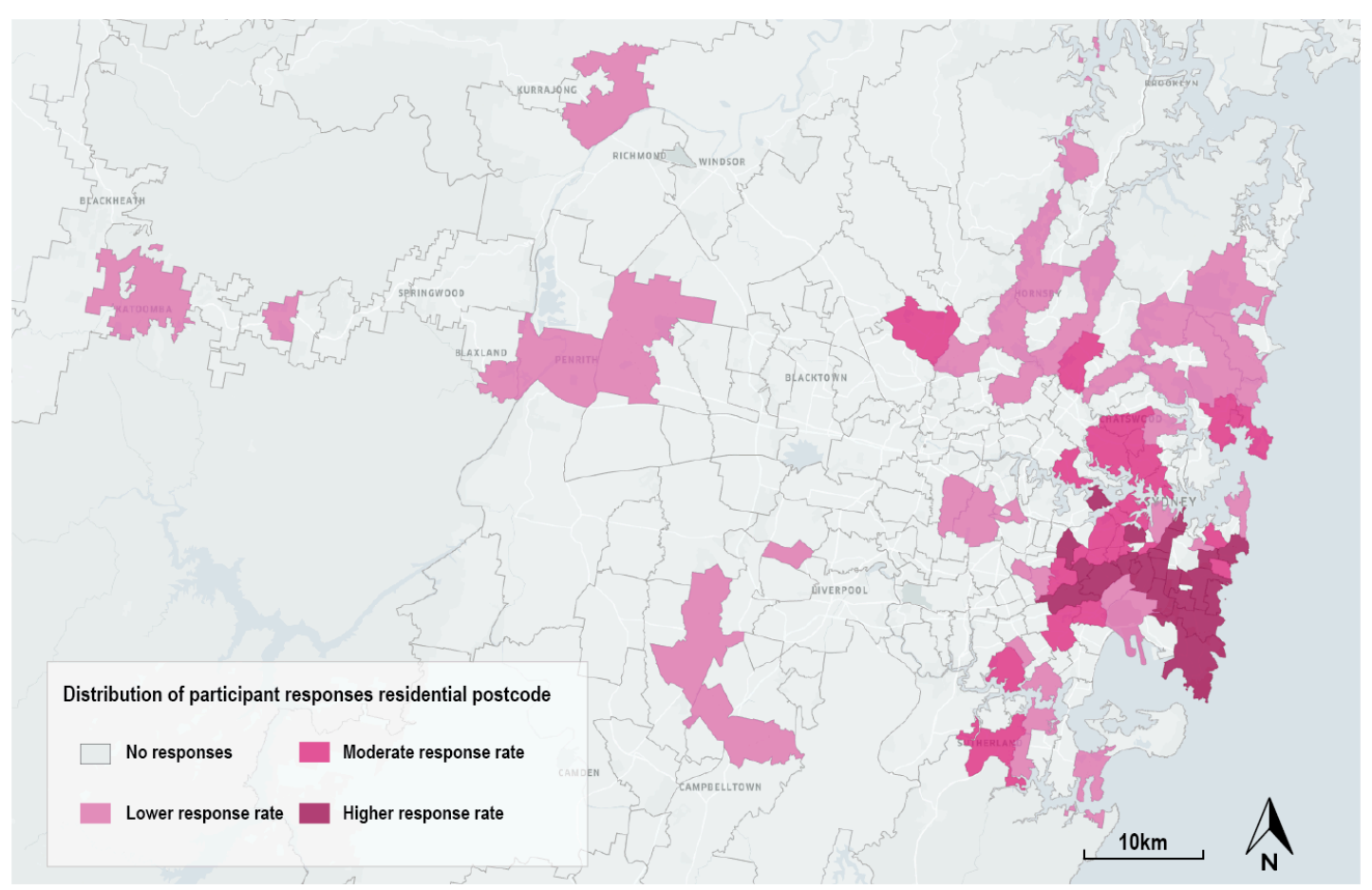

Figure 1. Distribution of survey participant respondents throughout Sydney, Australia.

research confirms anecdotal evidence, from a high volume of individuals with a wide geographic spread, of changes in cycling behaviour that occurred during this period.

There are, of course, limitations to consider. Firstly, although the target audience was general, approximately $92 \%$ of respondents reported their cycling frequency of at least once a month, with only $8 \%$ of respondents reporting infrequent to no cycle use. As such, further work specifically targeting those individuals without any strong past interest in cycling could be undertaken for a more rounded overview (despite evidence of new cyclists in responses). Secondly, this research primarily documents individuals' self-reporting of their own attitudes and behaviours, and the behaviours of others. While we can document these behaviours, a holistic view on attitudes is less accessible through this research method, only partially insinuated through observations.

As restrictions ease, these findings pose several implications for transport system planners: such as potential increased public support of active transport infrastructure, a potential permanent disruption of regular travel habits and potentially new design guidelines for resilient transport systems. Further, updated transport forecasts feeding infrastructure business cases should consider both the unprecedented potential behaviour change from reduced traffic flow observed, as well as the potential long-term impacts of new cyclists will have on networks. 
Do you feel that the

CoVID-19 situation has changed your views or

behaviours around cycling in any way? What about those around you? How?
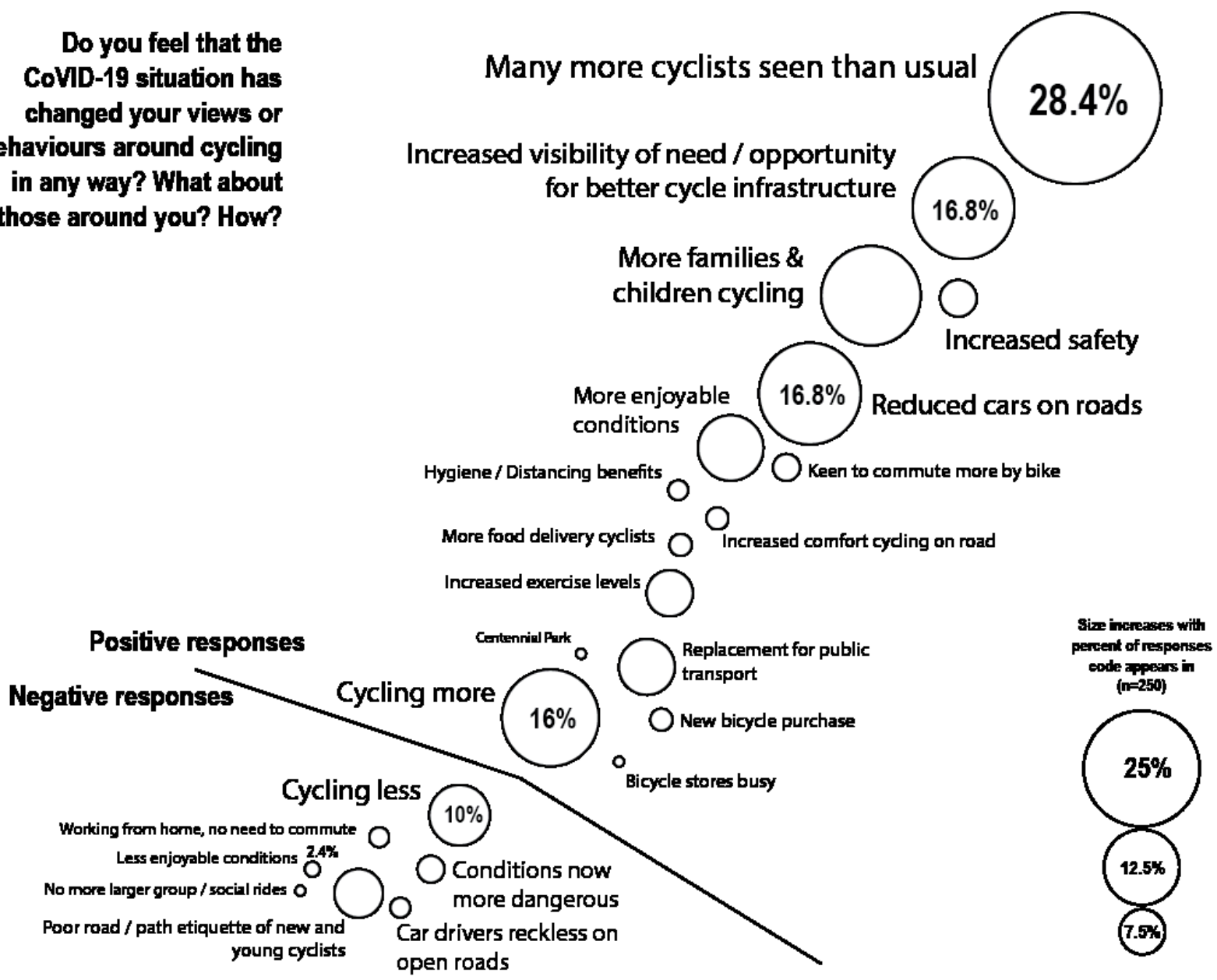

Figure 2. Codes. Summary of codes identified in respondents. Frequency of code indicated by circle size.

Further research can observe the extent which these behaviours continue to be carried out in future. This research can also complement findings with other cities of varying typologies which faced similar restrictions during this period. In this vein, it is envisioned that this research will contribute to others' findings of latent demand for active travel identified during this time, brought about through both quieter and safer road conditions.

\section{ACKNOWLEDGMENTS}

The author would like to thank the participants for their prompt and detailed responses and for those who shared the survey. The author would also like to thank the reviewers for their timely feedback on improving this article. Additional thanks to the author's $\mathrm{PhD}$ supervisors Christopher Pettit, Simone Zarpelon Leao and Tomasz Bednarz for the support of the wider research behind this. 
Appendix 1

Table A1. Themes. Key topics derived from codes.

\begin{tabular}{|c|c|}
\hline Theme & Key quotes \\
\hline $\begin{array}{l}\text { More cyclists } \\
\text { observed } \\
\text { than usual }\end{array}$ & $\begin{array}{l}\text { "Yes, there are a lot more people wanting to cycle to take short trips. It has given me additional appreciation for } \\
\text { how good cycleways are and how few we really have in Sydney. Would love to see more and encourage more } \\
\text { people to cycle." } \\
\text { "There are more people cycling and less cars. Feels safer and I have ridden on roads that I would normally avoid." } \\
\text { "Certainly has changed the views of those around me. My mum bought a bike, probably for the first time in } \\
\text { decades, and rides around our suburb for exercise. There are definitely more people riding, lots of middle aged } \\
\text { people getting around, either on their own or with kids, and lots more delivery riders." }\end{array}$ \\
\hline $\begin{array}{l}\text { Reduced } \\
\text { traffic } \\
\text { influence on } \\
\text { ridership }\end{array}$ & $\begin{array}{l}\text { "More people are clearly cycling in the pandemic due to reduced traffic. With many companies looking to } \\
\text { encourage WFH [working from home] going forward, surely this is a prime opportunity to shift trips to cycling." } \\
\text { "I have started cycling as a result of reduced traffic volumes." } \\
\text { "Totally. I have been riding bikes more than ever before. Conditions are so great with light traffic. I ride share } \\
\text { bikes Onyahbike so wherever I go around in Sydney, there is always one nearby to ride. That's awesome." }\end{array}$ \\
\hline $\begin{array}{l}\text { More families } \\
\text { and children } \\
\text { cycling }\end{array}$ & $\begin{array}{l}\text { "More family/recreational cyclists at present - fewer cars on the road helps this situation." } \\
\text { "I have been cycling for exercise and recreation more often, and have seen many others do the same. There are } \\
\text { also a lot more children and very young children out cycling or learning to ride as well." } \\
\text { "Yes, I think it's opened up the possibilities of cycling to more new people. I've seen many new riders, including } \\
\text { families and more delivery riders. They need to be supported, with safer infrastructure and with information (eg } \\
\text { navigational) to keep them riding rather than 'return to normal." } \\
\text { "I have noticed lots of families cycling for recreation and exercise. Increasing traffic of cycle delivery services. } \\
\text { More riders commuting, more riders recreation/exercise." }\end{array}$ \\
\hline $\begin{array}{l}\text { Higher } \\
\text { imperative to } \\
\text { invest in } \\
\text { cycling } \\
\text { infrastructure }\end{array}$ & $\begin{array}{l}\text { "The CoVID crisis has shown the latent interest in cycling in Sydney. Provided with quieter streets and limited } \\
\text { other avenues of exercise and transport (carrot and stick) the uptake in cycling has demonstrated what was } \\
\text { always known to be the case - that people in sydney want to ride. It is now incumbent on state and local } \\
\text { governments to rapidly facilitate this demand by strategically rolling out cheap tactical urbanism infrastructure." } \\
\text { "I was already a commuting cyclist. Covid19 has heightened the need for wider, more substantial, and connected } \\
\text { cycle ways and systems for encouraging cycling in Sydney. } \\
\text { I know some people who have begun cycling." } \\
\text { "Hoping it can be a catalyst for behaviour change and investment in cycling infrastructure to make it more } \\
\text { popular and safer for more people to ride more often. Has not changed my own behaviour except working from } \\
\text { home so no longer commuting by bike. Have seen heaps more kids and families on bikes which is great." } \\
\text { "The situation has highlighted that road traffic is a major barrier to people taking up cycling for fun and probably } \\
\text { commuting too. With hardly any traffic people of all ages and abilities and flocking the streets, parks and shared } \\
\text { paths to ride. I believe more people will want to commute by bike post covid. My area has seen a massive rise in } \\
\text { the number of recreational riders. Poor infrastructure, low prioritisation for cyclists versus cycles have been } \\
\text { barriers in the past. The models used to justify business cases roads need to be reassessed given the growing } \\
\text { number of people wanting to use active transport." }\end{array}$ \\
\hline $\begin{array}{l}\text { Increased } \\
\text { motivation / } \\
\text { willingness to } \\
\text { cycle in future }\end{array}$ & $\begin{array}{l}\text { "I've noticed many more children + caregivers cycling around, which is great! I hope this helps with driver } \\
\text { tolerance and city planning towards a more comprehensive cycle-friendly network. My own views and } \\
\text { behaviours stay the same, although I am considering an ebike so I can commute easily and regularly when I return } \\
\text { to the office." } \\
\text { "Yes personally I bought a bike to enable independent transport as I have no car." }\end{array}$ \\
\hline $\begin{array}{l}\text { Concerns in } \\
\text { safety from } \\
\text { higher } \\
\text { volume of } \\
\text { cyclists, } \\
\text { inexperienced } \\
\text { riders and } \\
\text { cars driving } \\
\text { reckless on } \\
\text { open roads }\end{array}$ & $\begin{array}{l}\text { "I still enjoy cycling however COVID-19 has definitely brought out a lot more riders/cyclists that weren't there } \\
\text { before. There are people cycling that don't normally cycle and aren't aware of basic cycling etiquette... I'm talking } \\
\text { about keeping to the left if you're riding as a family (I can forgive kids but adults should know better), two friends } \\
\text { riding "together" with one riding on the shared pedestrian-cycling footpath chatting to another riding on the } \\
\text { cycle path which runs next to an active driving lane... This placed riders behind the latter rider in an unnecessarily } \\
\text { dangerous situation looking for a gap in traffic to overtake. It has been interesting to see the spike in sales of } \\
\text { bicycles and indoor trainers. It will be interesting to see whether these changes are sustained after COVID-19." } \\
\text { "I've noticed how less traffic allows me to look at new routes and feel safer riding on the road. I have also } \\
\text { discovered that Centennial Park is more dangerous without cars" }\end{array}$ \\
\hline
\end{tabular}




\begin{tabular}{|c|c|}
\hline & $\begin{array}{l}\text { "It is more dangerous to cycle because cars can drive faster due to less traffic. As a result, my trip is less } \\
\text { enjoyable." } \\
\text { "I have noticed more cyclists, but many have no clue about basic cycling etiquette." }\end{array}$ \\
\hline $\begin{array}{l}\text { Short-term } \\
\text { health and } \\
\text { hygiene } \\
\text { benefits }\end{array}$ & $\begin{array}{l}\text { "Yes, I prefer to cycle more at the moment to allow for greater ability to socially distance. It also allows me the } \\
\text { ability to get more exercise as I feel I'm a lot more sedentary during this work from home period." } \\
\text { "Yes! I am cycling more for necessary trips like shopping than taking the bus. Very grateful to have a bike, and } \\
\text { cycling confidence in this hectic Sydney road environment, so I can easily keep my distance to others and avoid } \\
\text { public transport during this time." } \\
\text { "I would like to try commuting by bicycle rather than catch the bus and have a higher risk of Covid infection." } \\
\text { "I see it [cycling] as even more important and urgent for fitness, air quality, congestion, and urban resilience." }\end{array}$ \\
\hline $\begin{array}{l}\text { Shift in } \\
\text { commute / } \\
\text { public } \\
\text { transport } \\
\text { decrease }\end{array}$ & $\begin{array}{l}\text { "Made me want to cycle more rather than take public transport. This is true for friends of mine also." } \\
\text { "I'm spending more time on my bike now. When we do return to work in the office I plan to commute by bike } \\
\text { every day" } \\
\text { "I would now be much more likely to cycle or walk than take the bus." }\end{array}$ \\
\hline
\end{tabular}

This is an open-access article distributed under the terms of the Creative Commons Attribution 4.0 International License (CCBY-SA-4.0). View this license's legal deed at https://creativecommons.org/ licenses/by-sa/4.0 and legal code at https://creativecommons.org/licenses/by-sa/4.0/legalcode for more information. 


\section{REFERENCES}

Austroads. 2019. "National Cycling Participation Survey.” https://austroads.com.au/publications/ active-travel/ap-c91-19.

Braun, Virginia, and Victoria Clarke. 2006. “Using Thematic Analysis in Psychology.” Qualitative Research in Psychology 3 (2): 77-101. https://doi.org/10.1191/1478088706qp063oa.

Heymes, Capucine. 2019. "Stationless in Sydney: The Rise and Decline of Bikesharing in Australia." Transport Findings, March. https://doi.org/10.32866/7615.

Rissel, Chris, Dafna Merom, Adrian Bauman, Jan Garrard, Li Ming Wen, and Carolyn New. 2010. "Current Cycling, Bicycle Path Use, and Willingness to Cycle More-Findings From a Community Survey of Cycling in Southwest Sydney, Australia." Journal of Physical Activity and Health 7 (2): 267-72. https://doi.org/10.1123/jpah.7.2.267.

Standen, Christopher, Melanie Crane, Andrew Collins, Stephen Greaves, and Chris Rissel. 2017. "Determinants of Mode and Route Change Following the Opening of a New Cycleway in Sydney, Australia." Journal of Transport $\Xi^{2}$ Health 4 (March): 255-66. https://doi.org/10.1016/ j.jth.2016.10.004. 